\section{An Introduction to Capital Controls}

\section{Christopher J. Neely}

M oreover, it may well be asked whether we can take it for granted that a return to freedom of exchanges is really a question of time. Even if the reply were in the affirmative, it is safe to assume that after a period of freedom the regime of control will be restored as a result of the next economic crisis.

- Paul Einzig, Exchange Control, MacMillan and Company, 1934.

Currency controls are a risky, stopgap measure, but some gaps desper ately need to be stopped.

- Paul Krugman, "Free Advice: A Letter to Malaysia's Prime Minister," Fortune, September 28, 1998.

U nlike many topics in international economics, capital controls-taxes or restrictions on international transactions in assets like stocks or bonds- have received cursory treatment in textbooks and scant attention from researchers. The consensus among economists has been that capital controls- like tariffs on goods-are obviously detrimental to economic efficiency because they prevent productive resources from being used where they are most needed. As a result, capital controls gradually had been phased out in developed countries during the 1970s and 1980s, and by the 1990 s there was substantial pressure on lessdeveloped countries to remove their restrictions, too (N ew York Times, 1999). The topic al most had been relegated to a curiosity.

Several recent developments, however, have rekindled interest in the use and study of capital controls. First, the resumption of large capital flows - trade in assetsto developing countries during the late 1980 s and early 1990s created new problems for policymakers. Second, a string of exchange rate/financial crises during the 1990s - the European M onetary System crises of 1992-93, the M exican crisis of 1994 and the Asian financial crisis of 1997-98-focused attention on the asset transactions that precipitated them. In particular, Malaysia's adoption of capital controls on September 1, 1998, has prompted increased media attention and has renewed debate on the topic.

Modern capital controls were developed by the belligerents in World War I to maintain a tax base to finance wartime expenditures. Controls began to disappear after the war, only to return during the Great Depression of the 1930s. At that time, their purpose was to permit countries greater ability to reflate their economies without the danger of capital flight. In fact, the International M onetary Fund (IMF) Articles of Agreement (Article VI, section 3) signed at the Bretton-Woods conference in 1944 explicitly permitted capital controls. ${ }^{1}$ One of the architects of those articles, John M aynard Keynes, was a strong proponent of capital controls and the IMF often was seen as such during its early years. During the Bretton-Woods era of fixed-exchange rates, many countries limited asset transactions to cope with balance-of-payments difficulties. But, recognition of the costs and distortions created by these restrictions led to their gradual removal in developed countries over the last 30 years. The United States, for example, removed its most prominent capital controls in 1974 (Congressional Quarterly Service, 1977). During the last 10 years even less-developed countries began to liberalize trade in assets.

The purpose of this article is to introduce Review readers to the debate on capital controls, to explain the purposes
1 "Article VI. Section 3. Controls of capital transfers: Members may exercise such controls as are necessary to regulate international capital movements, but no member may exercise these controls in a manner which will restrict payments for current transactions or which will unduly delay transfers of funds in settlement of commitments, except as provided in Article VII, Section 3(b) and in Article XIV, Section 2." 
2 The U.S. Department of Commerce does not recognize "real" assets as a separate class. The purchase of assets such as foreign production facilities is recorded under financial assets in their accounts (Department of Commerce, 1990).

\section{The capital account records} both loans and asset purchases because both involve buying a claim on future income. $\mathrm{A}$ bank making a car loan obtains a legal claim on the borrower's future income.

4 Equity investment is considered portfolio investment in national accounts until it exceeds 10 percent of the market capitalization of the firm, then it is considered direct investment.

5 The current account records trade in goods, services, and unilateral transfers. A nation's capital account balance must be equal to and opposite in sign from its current account balance because a nation that imports more goods and services than it exports must pay for those extra imports by selling assets or borrowing money. The sum of the current account balance and the capital account balance is the balance of payments.

6 The composition as well as the magnitude of capital flows also may influence the sustainability of policies, as will be discussed in section 3. and costs of controls and why some advocate their reintroduction. To lay the groundwork for understanding restrictions on capital flows, the next section of the article describes capital flows and their benefits. The third section characterizes the most common objectives of capital controls with an emphasis on the recent debate about using controls to foster macroeconomic stability. Then the many types of capital controls are distinguished from each other and their effectiveness and costs are considered. In addition, accompanying shaded inserts outline specific case studies in capital controls: the U.S. Interest Equalization Tax of 1963, the Chilean encaje of the 1990s, and the restrictions imposed by Malaysia in September 1998.

\section{CAPITAL FLOWS}

To understand what capital controls do, it is useful to examine capital flows- trade in real and financial assets. International purchases and sales of existing real and financial assets are recorded in the capital account of the balance of payments. ${ }^{2}$ Real assets include production facilities and real estate while financial assets include stocks, bonds, loans, and claims to bank deposits. ${ }^{3}$ Capital account transactions often are classified into portfolio investment and direct investment. Portfolio investment encompasses trade in securities like stocks, bonds, bank loans, derivatives, and various forms of credit (commercial, financial, guarantees). Direct investment involves the purchase of real estate, production facilities, or substantial equity investment. ${ }^{4}$ When a German corporation, BMW, for example, builds an automobile factory in South Carolina, that is direct investment. On the other hand, when U.S. investors buy Mexican government bonds, that is portfolio investment.

A country is said to have a deficit in the capital account if it is accumulating net claims on the rest of the world by purchasing more assets and/or making more loans to the rest of the world than it is receiving. A country, like Japan, with a capital account deficit is also said to experience a capital outflow. Accumulating claims on the rest of the world is a form of national saving. Conversely, a country is said to have a surplus in the capital account-or a capital inflow - if the rest of the world is accumulating net claims on it, as is the case with the United States. ${ }^{5}$ Just as individuals must avoid borrowing excessively, policymakers must make sure that the rest of the world does not accumulate too many net claims on their countries- in other words, that their countries do not sell assets/borrow at an unsustainable rate. ${ }^{6}$

\section{Benefits of Capital Flows}

Economists have long argued that trade in assets (capital flows) provides substantial economic benefits by enabling residents of different countries to capitalize on their differences. Fundamentally, capital flows permit nations to trade consumption today for consumption in the futureto engage in intertemporal trade (Eichengreen, et al. 1999). Because Japan has a population that is aging more rapidly than that of the United States, it makes sense for Japanese residents to purchase more U.S. assets than they sell to us. This allows the Japanese to save for their retirement by building up claims on future income in the United States while permitting residents of the United States to borrow at lower interest rates than they could otherwise pay.

A closely related concept is that capital flows permit countries to avoid large falls in national consumption from economic downturn or natural disaster by selling assets to and/or borrowing from the rest of the world. For example, after an earthquake devastated southern Italy on N ovember 23, 1980, leaving 4,800 people dead, Italians borrowed from abroad (ran a capital account surplus) to help repair the damage. Figure 1 illustrates the time series of the Italian capital account from 1975 through 1985.

A third benefit is that capital flows permit countries as a whole to borrow in order to improve their ability to produce goods and services in the future- like individuals borrowing to finance an educa- 
tion. To cite just one example, between 1960 and 1980 Koreans borrowed funds from the rest of the world equal to about 4.3 percent of gross domestic product (GDP) annually to finance investment during Korea's period of very strong growth (see Figure 2).

These arguments for free capital mobility are similar to those that are used to support free trade. Countries with different age structures, saving rates, opportunities for investment, or risk profiles can benefit from trade in assets. More recently, economists have emphasized other benefits of capital flows such as the technology transfer that often accompanies foreign investment, or the greater competition in domestic markets that results from permitting foreign firms to invest locally (Eichengreen, et al. 1999). The benefits of capital flows do not come without a price, however. Because capital flows can complicate economic policy or even be a source of instability themselves, governments have used capital controls to limit their effects (J ohnston and Tamirisa, 1998).

\section{PURPOSES OF CAPITAL CONTROLS}

A capital control is any policy designed to limit or redirect capital account transactions. This broad definition suggests that it will be difficult to generalize about capital controls because they can take many forms and may be applied for various purposes (Bakker, 1996). Controls may take the form of taxes, price or quantity controls, or outright prohibitions on international trade in assets. ${ }^{7}$

\section{Revenue Generation and Credit Allocation}

The first widespread capital controls were adopted in WWI as a method to finance the war effort. At the start of the war, all the major powers suspended their participation in the gold standard for the duration of the conflict but maintained fixed-exchange rates. All the belligerents restricted capital outflows, the purchase of foreign assets or loans abroad. These

\section{Figure 1}

Italian Capital Account Surplus as a Percentage of GDP

Percent

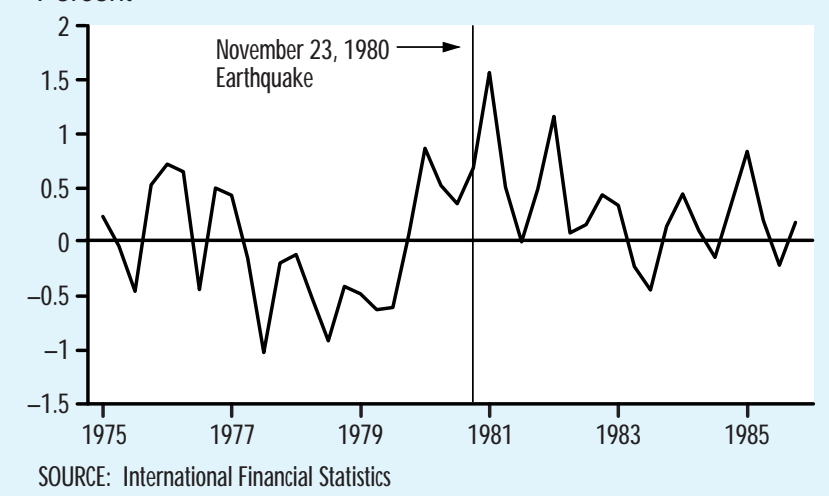

\section{Figure 2}

South Korean Growth and Capital Surplus

Percent

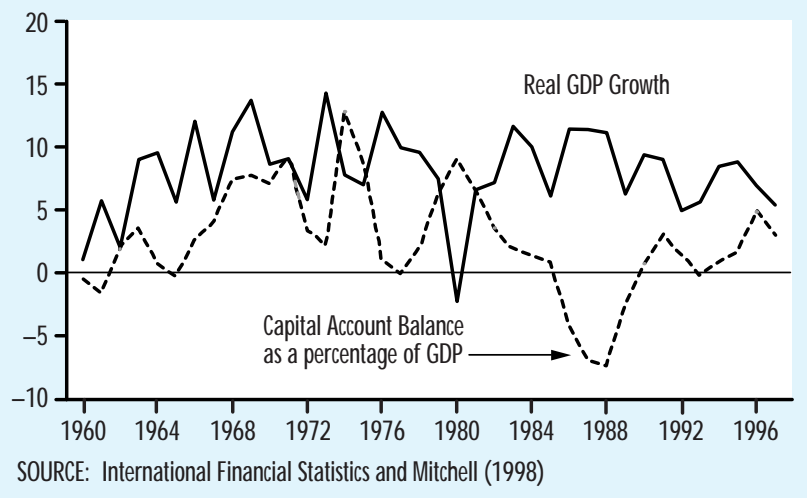

restrictions raised revenues in two ways. First, by keeping capital in the domestic economy, it facilitated the taxation of wealth and interest income (Bakker, 1996). Second, it permitted a higher inflation rate, which generated more revenue. Capital controls also reduced interest rates and therefore the government's borrowing costs on its own debt (Johnston and Tamirisa, 1998). Since WWI, controls on capital outflows have been used similarly in other - mostly developing- economies to generate revenue for governments or to permit them to allocate credit domestically without risking capital flight (Johnston and
7 Alesina, Grilli, and MilesiFerretti (1994) and Grilli and Milesi-Ferretti (1995) empirically examine factors associated with capital controls. 


\section{REVIEW}

NOVEMBER/ DECEMBER 1999

Table 1

\section{Purposes of Capital Controls}

\begin{tabular}{|c|c|c|c|}
\hline $\begin{array}{l}\text { Purpose of } \\
\text { Control }\end{array}$ & Method & $\begin{array}{l}\text { Direction } \\
\text { of Control }\end{array}$ & Example \\
\hline $\begin{array}{l}\text { Generate Revenue/ } \\
\text { Finance War Effort }\end{array}$ & $\begin{array}{l}\text { Controls on capital outflows permit a country to run } \\
\text { higher inflation with a given fixed-exchange rate and } \\
\text { also hold down domestic interest rates. }\end{array}$ & Outflows & $\begin{array}{l}\text { Most belligerents } \\
\text { during WWI } \\
\text { and WWII }\end{array}$ \\
\hline $\begin{array}{l}\text { Financial Repression/ } \\
\text { Credit Allocation }\end{array}$ & $\begin{array}{l}\text { Governments that use the financial system to reward } \\
\text { favored industries or to raise revenue, may use capital } \\
\text { controls to prevent capital from going abroad to seek } \\
\text { higher returns. }\end{array}$ & Outflows & $\begin{array}{l}\text { Common in } \\
\text { developing } \\
\text { countries }\end{array}$ \\
\hline $\begin{array}{l}\text { Correct a Balance of } \\
\text { Payments Deficit }\end{array}$ & $\begin{array}{l}\text { Controls on outflows reduce demand for foreign assets } \\
\text { without contractionary monetary policy or devalua- } \\
\text { tion. This allows a higher rate of inflation than other- } \\
\text { wise would be possible. }\end{array}$ & Outflows & $\begin{array}{l}\text { U.S. interest } \\
\text { equalization tax, } \\
1963-74\end{array}$ \\
\hline $\begin{array}{l}\text { Correct a Balance of } \\
\text { Payments Surplus }\end{array}$ & $\begin{array}{l}\text { Controls on inflows reduce foreign demand for domes- } \\
\text { tic assets without expansionary monetary policy or } \\
\text { revaluation. This allows a lower rate of inflation than } \\
\text { would otherwise be possible. }\end{array}$ & Inflows & $\begin{array}{l}\text { German Bardepot } \\
\text { scheme, 1972-74 }\end{array}$ \\
\hline $\begin{array}{l}\text { Prevent Potentially } \\
\text { Volatile Inflows }\end{array}$ & $\begin{array}{l}\text { Restricting inflows enhances macroeconomic stability } \\
\text { by reducing the pool of capital that can leave a coun- } \\
\text { try during a crisis. }\end{array}$ & Inflows & $\begin{array}{l}\text { Chilean encaje, } \\
1991-98\end{array}$ \\
\hline $\begin{array}{l}\text { Prevent Financial } \\
\text { Destabilization }\end{array}$ & $\begin{array}{l}\text { Capital controls can restrict or change the composition } \\
\text { of international capital flows that can exacerbate dis- } \\
\text { torted incentives in the domestic financial system. }\end{array}$ & Inflows & $\begin{array}{l}\text { Chilean encaje, } \\
1991-98\end{array}$ \\
\hline $\begin{array}{l}\text { Prevent Real } \\
\text { Appreciation }\end{array}$ & $\begin{array}{l}\text { Restricting inflows prevents the necessity of monetary } \\
\text { expansion and greater domestic inflation that would } \\
\text { cause a real appreciation of the currency. }\end{array}$ & Inflows & $\begin{array}{l}\text { Chilean encaje, } \\
1991-98\end{array}$ \\
\hline $\begin{array}{l}\text { Restrict Foreign } \\
\text { Ownership of } \\
\text { Domestic Assets }\end{array}$ & $\begin{array}{l}\text { Foreign ownership of certain domestic assets- espe- } \\
\text { cially natural resources- can generate resentment. }\end{array}$ & Inflows & $\begin{array}{l}\text { Article } 27 \text { of } \\
\text { the Mexican } \\
\text { constitution }\end{array}$ \\
\hline $\begin{array}{l}\text { Preserve Savings } \\
\text { for Domestic Use }\end{array}$ & $\begin{array}{l}\text { The benefits of investing in the domestic economy } \\
\text { may not fully accrue to savers so the economy, as } \\
\text { a whole, can be made better off by restricting the } \\
\text { outflow of capital. }\end{array}$ & Outflows & \\
\hline $\begin{array}{l}\text { Protect Domestic } \\
\text { Financial Firms }\end{array}$ & $\begin{array}{l}\text { Controls that temporarily segregate domestic financial } \\
\text { sectors from the rest of the world may permit domestic } \\
\text { firms to attain economies of scale to compete in world } \\
\text { markets. }\end{array}$ & $\begin{array}{l}\text { Inflows and } \\
\text { Outflows }\end{array}$ & \\
\hline
\end{tabular}


Tamirisa). Table 1 summarizes the purposes of capital controls.

\section{Balance of Payments Crises}

During the Great Depression, controls simultaneously were used to achieve greater freedom for monetary policy and exchange rate stability-goals that have remained popular. To understand why controls have been used in this way, it is necessary to understand balance of payments problems and their solutions (Johnston and Tamirisa, 1998). At a given exchange rate, a country often will want to collectively purchase more goods, services and assets than the rest of the world will buy from it. Such an imbalance is called a balance of payments deficit and may come about for any one of a number of reasons: 1) The domestic business cycle may be out of sync with that of the rest of the world; 2) There may have been a rapid change in the world price of key commodities like oil; 3) Expansionary domestic policy may have increased demand for the rest of the world's goods; 4) Large foreign debt interest obligations may surpass the value of the domestic economy's exports; 5) Or, a perception of deteriorating economic policy may have reduced international demand for domestic assets. ${ }^{8}$ In the absence of some combination of exchange rate and monetary policy by the deficit country, excess demand for foreign goods and assets would bid up their prices- typically through a fall in the foreign exchange value (a devaluation or depreciation) of the domestic currency-until the deficit was eliminated. ${ }^{9}$

There are four policy alternatives to correct an imbalance in international payments: 1) Permit the exchange rate to change, as described above; 2 ) Use monetary policy-unsterilized foreign exchange intervention - to correct the imbalance through domestic demand; 3) Attempt to sterilize the monetary changes to isolate the domestic economy from the capital flows; and 4) Restrict capital flows. ${ }^{10}$ Each alternative has disadvantages.

W hen domestic residents purchase more goods and assets from foreigners than foreigners purchase from domestic residents, the exchange rate (the price of foreign currency) tends to rise. If the exchange rate is flexible, the foreign currency tends to appreciate and the domestic currency tends to depreciate. The depreciation of the domestic currency raises prices of imported goods and assets to domestic residents and lowers the prices of domestic goods and assets on world markets, reducing the relative demand for foreign goods and assets until the imbalance in the balance of payments is eliminated. A country with a fixed exchange rate similarly may correct a balance of payments deficit by changing the exchange rate peg-devaluing the currency-but this option foregoes the benefits of exchange rate stability for international trade and policy discipline. In addition, it may reduce the public's confidence in the monetary authorities' antiinflation program.

If a government is committed to maintaining a particular fixed exchange rate, on the other hand, its central bank can prevent the depreciation of its currency with contractionary monetary policy-by selling domestic bonds. ${ }^{11}$ Alternatively, the central bank might sell foreign exchange to affect the monetary base, in which case the action is known as unsterilized foreign exchange intervention. In either case, such a sale lowers the domestic money supply and raises domestic interest rates- lowering domestic demand for imports- while reducing the prices of domestic goods, services, and assets relative to their foreign counterparts. The reduced demand and higher prices for foreign goods, services, and assets would eliminate a balance of payments deficit. However, this defense of the exchange rate requires that monetary policy be devoted solely to maintaining the exchange rate; it cannot be used to achieve independent domestic inflation or employment goals. In this case, for example, the contraction temporarily will reduce domestic demand and employment, which may be undesirable. A country that uses monetary policy to defend the exchange rate in the face of imbalances in international payments is said to subordinate
8 Often, the term "balance of payments deficit" describes an imbalance in the current account (goods, services, factor payments, and unilateral transfers). Here, it describes the sum of the current account and the capital account. Countries also may demand fewer goods and assets from the rest of the world - balance of payments surpluses- but this article concentrates on balance of payments deficits because most countries find balance of payments surpluses easier to manage.

9 When a flexible exchange rate currency gains or loses value, it is said to appreciate or depreciate, respectively. Fixed-rate currencies are said to be revalued or devalued when their price rises or falls.

10 There are other policiesfiscal and regulatory- that may be used to manage the effects of capital flows but they will be ignored to simplify the discussion.

11Foreign exchange operations that do not affect the domestic monetary base are called "sterilized," while those that do affect the monetary base are called "unsterilized." Sales of any asset would tend to lower the domestic money supply and raise interest rates because when the monetary authority receives payment for the asset, the payment ceases to be part of the money supply. Fiscal policy also may have an effect on exchange rates but taxing and spending decisions usually are more constrained than monetary decisions. 
12 of course, capital outflows are not necessary to force devaluation. If the domestic economy still demands more goods and services than it supplies to the rest of the world, the exchange rate cannot be maintained without a monetary contraction.

${ }^{13}$ Countries that face balance of payments surpluses- the desire to purchase fewer goods and services from the rest of the world at the fixed-exchange rate- would restrict capital inflows, rather than outflows, to reduce demand for their own assets.

14 If there is still excess demand for foreign goods, the fixedexchange rate will still be only temporarily sustainable.

${ }^{15} \mathrm{~A}$ nominal appreciation is a rise in the foreign exchange value of a country's currency. A real appreciation is a rise in the relative price of domestic goods and services compared to foreign goods and services. This may result from a nominal appreciation, domestic inflation that is higher than foreign inflation, or some combination of the two.

16 Empirically, Edwards (1998b) finds a consistent, but limited, tendency toward real appreciation from capital inflows. domestic monetary policy to exchange rate concerns.

Rather than subordinate monetary policy to maintaining the exchange rate, some central banks have attempted to recapture some monetary independence by sterilizing - or reversing - the effect of foreign exchange operations on the domestic money supply. Sterilization of sales of foreign exchange (foreign bonds), for example, would require the central bank to buy an equal amount of domestic bonds, leaving domestic interest rates unchanged after the inflow. It generally is believed that sterilized intervention does not affect the exchange rate and so it is not very effective in recapturing monetary independence (Edwards, 1998b).

If international investors don't believe that the monetary authorities will defend the exchange rate with tighter monetary policy, they will expect devaluation - a fall in the relative price of domestic goods and assets- and will sell domestic assets to avoid a loss. Such a sale increases relative demand for foreign assets, exacerbating the balance of payments deficit, and speeds the devaluation. ${ }^{12}$

Capital flows play a crucial role in balance of payments crises in two ways. Swings in international capital flows can create both a balance-of-payments problem and-if the exchange rate is not defended-expedite devaluation under fixedexchange rates. Thus, in the presence of free capital flows, a country wishing to maintain a fixed-exchange rate must use monetary policy solely for that purpose. As McKinnon and Oates (1966) argued, no government can maintain fixed-exchange rates, free capital mobility, and have an independent monetary policy; one of the three options must give. This is known as the "incompatible trinity" or the trilemma (Obstfeld and Taylor, 1998). Policymakers wishing to avoid exchange-rate fluctuation and retain scope for independent monetary policy must choose the fourth option, restrict capital flows.

By directly reducing demand for foreign assets and the potential for speculation against the fixed-exchange rate, controls on capital outflows allow a country to maintain fixed-exchange rates and an independent domestic monetary policy while alleviating a balance-of-payments deficit. ${ }^{13}$ The monetary authorities can meet both their internal goals (employment and inflation) and their external goals (balance of payments). ${ }^{14}$ Thus, capital controls are sometimes described in terms of the choices they avoid: to prevent capital outflows that, through their effect on the balance of payments, might either endanger fixed-exchange rates or independence of monetary policy.

\section{Real Appreciation of the Exchange Rate}

While capital outflows can create balance-of-payments deficits, capital inflows can cause real appreciation of the exchange rate. ${ }^{15}$ During the 1980 s and 1990s a number of developing countries completed important policy reforms that made them much more attractive investment environments. Eichengreen, et al. (1999) report that net capital flows to developing countries tripled from $\$ 50$ billion in 1987-89 to more than $\$ 150$ billion in 1995-97. These large capital inflows to the reforming countries tended to drive up the prices of domestic assets. For countries with flexible exchange rates, the exchange rates appreciated, raising the relative prices of the domestic countries' goods. For countries with fixed-exchange rates, the increased demand for domestic assets led the monetary authorities to buy foreign exchange (sell domestic currency), increasing the domestic money supply and ultimately the prices of domestic goods and assets. In either case, the prices of domestic goods and assets rose relative to those in the rest of the world-a real appreciation-making domestic exported goods less competitive on world markets and hurting exporting and import-competing industries. ${ }^{16}$ Because of these effects, the problem of real exchange-rate appreciation from capital inflows is described variously as real exchange-rate instability, real appreciation, or loss of competitiveness. 
Countries have a number of policy options to prevent real appreciation in the face of capital inflows (Goldstein, 1995; Corbo and Hernandez, 1996). Permitting the exchange rate to change still results in nominal and real appreciation but avoids domestic inflation. A very common tactic for fixed exchange-rate regimes is to sterilize the monetary effects of the inflows, preventing an expansion of the money supply by reversing the effect on the domestic money market (Edwards, 1998b). It generally is believed that sterilization is not very effective in recapturing monetary independence as it keeps domestic real interest rates high and leads to continued inflows. Sterilization of inflows also is a potentially expensive strategy for the government as the domestic bonds that the central bank sells may pay higher interest than the foreign bonds the central bank buys. Fiscal contraction is an effective way to prevent real appreciation because it lowers domestic interest rates, and likewise, the demand for domestic assets; but raising taxes and/or reducing government spending may be politically unpalatable. Because of the problems associated with these first three policies, countries like Brazil, Chile, and Columbia chose to use capital controlsrestricting purchase of domestic assets (inflows) - to try to prevent real appreciation and substitute for fiscal policy flexibility in the face of heavy inflows.

\section{Theories of the Second Best}

M ore recently, economists have considered other circumstances- other than balance-of-payments needs or real appreciation-under which capital controls might be a useful policy. As a rule, economists emphasize that restrictions on trade and investment impose costs on the economy. There are exceptions to that rule, however. Taxes and quantitative restrictions may be good for the economy-welfare improving, in technical jargon-if they are used to correct some other, pre-existing distortion to free markets that cannot be corrected otherwise. The idea that a tax or quantitative restriction can improve economic wel- fare in this way is called a "theory of the second best." 17

Capital controls preserve domestic savings for domestic use. From a national point of view, there might be benefits from a greater rate of domestic investment that do not fully accrue to the investors. For example, domestic savers might invest disproportionately overseas because of political risk of expropriation or a desire to escape taxation. In either case, the nation as a whole could be made better off by limiting or taxing domestic investment abroad (Harberger, 1986).

The infant industry argument- an old idea often used to justify tariffs in goods markets - has been resurrected to rationalize the use of capital controls on both inflows and outflows. This idea starts with the premise that small, domestic firms are less efficient than larger, foreign firms and so will be unable to compete on an equal basis. To permit small domestic firms to grow to the efficient scale that they need to enjoy to compete in world markets, they must be protected temporarily from international competition by trade barriers. As applied to capital markets, the argument urges that capital controls be used to protect underdeveloped financial markets from foreign competition. The problem with this argument, as in goods markets, is that protected industries often never grow up and end up seeking perpetual protection.

\section{Financial Sector Distortions}

In reality, capital controls rarely have been imposed in a well-thought-out way to correct clearly defined pre-existing distortions. Instead, capital controls most often have been used as a tool to postpone difficult decisions on monetary and fiscal policies. Recently, however, the case has been made that capital controls may be the least disadvantageous solution to the destabilizing effects of capital flows on inadequately regulated financial systems.

Recall that when a country with a fixed-exchange rate has a net capital outflow, the increase in relative demand for foreign assets means that there is insuffi-
17 The classic example of a tax that improves welfare is the one imposed on a polluting industry. Because a polluting industry imposes non-market costs on others, for which it does not compensate them, a government could improve everyone's well being if it were to tax pollution. The factory would produce less pollution and people would be happier. The desire to meet employment goals with an independent monetary policy is really a version of a "second best" story in which the pre-existing distortion is price inertia (or a similar friction) in the real economy that causes monetary policy to have real effects (Dooley, 1996). 
cient demand for domestic goods and assets at the fixed-exchange rate. The domestic monetary authorities may conduct contractionary monetary policyraise domestic interest rates to make their assets more attractive- or lower the prices of their goods and assets (devalue the currency). This is a special case of a balanceof-payments deficit and presents the same choice - to raise interest rates or devaluebut in the case of a sudden capital outflow, the crisis manifests itself in large sudden capital outflows rather than more gradual balance-of-payments pressures from other causes. Governments must choose between high interest rates coupled with some capital outflows or an exchange rate devaluation that provokes fear of inflation and policy instability leading to greater capital outflows. In either case, a serious recession seems unavoidable.

The recent case for capital controls recognizes that a monetary contraction not only slows economic activity through the normal interest-rate channels, but also can threaten the health of the economy through the banking system (Kaminsky and Reinhart, 1999). If the monetary authorities raise interest rates, they increase the costs of funds for banks and-by slowing economic growth - reduce the demand for loans and increase the number of nonperforming loans. Choosing to devalue the currency rather than raising interest rates does not necessarily help banks either, as they may have borrowed in foreign currency. A devaluation would increase the banks' obligations to their foreign creditors. Thus, capital outflows from the banking system pose special problems for the monetary authorities, as banks' liabilities are usually implicitly or explicitly guaranteed by the government.

Indeed, the very nature of the financial system creates perverse incentives (distortions) that international capital flows often exacerbate (M ishkin, 1998). For example, in a purely domestic context, banks have incentives to make risky loans, as their losses are limited to the owners' equity capital, but their potential profits are unlimited. The existence of deposit insurance worsens this problem by reducing depositors' incentive to monitor their banks' loan portfolio for excessive risk. Deposit insurance, in turn, exists precisely because depositors can not easily monitor the riskiness of their banks. In the absence of deposit insurance, depositors would find it difficult to tell good banks from bad banks and would withdraw their money at any sign of danger to the bank. Once some depositors began to withdraw their money from the bank, all depositors would try to do so, forcing the bank to close, even if its underlying assets were productive (Diamond and Dybvig, 1983). This puts the whole banking system at risk.

To avoid this problem, most developed countries combine implicit or explicit insurance of bank deposits with government regulation of depository institutions, especially their asset portfolios (loans). In emerging markets, however, banking regulation is much more difficult as the examiners are less experienced, have fewer resources and less strict accounting standards by which to operate. Thus, banking problems are more serious in emerging markets.

Large international capital inflows, especially short-term foreign borrowing, can exacerbate these perverse incentives and pose a real danger to banking systems. Domestic banks often view borrowing from abroad in foreign currency sources as a low-cost source of funds-as long as the domestic currency is not devalued. With this additional funding, banks expand into unfamiliar areas, generating risky loans that potentially create systemic risk to the banking system (Eichengreen, 1999; Garber, 1998; Goldstein, 1995; Dornbusch, 1998). If capital outflows force a devaluation, the foreign-currency denominated debts of the banking system increase when measured in the domestic currency, possibly leading to bank failures. The banking system is a particularly vulnerable conduit by which capital flows can destabilize an economy because widespread bank failures impose large costs on taxpayers and can disrupt the payments system and the relationships between banks and firms who borrow from them (Friedman and Schwartz, 1963; Bernanke, 1983). The 
difficulty of effective banking regulation cre ates an argument for capital controls as a second-best solution to the existence of the distorted incentives in the banking system. ${ }^{18}$

There are two ways in which capital controls might be imposed to limit capital flow fluctuations and achieve economic stability. First, capital controls may be used to discourage capital outflows in the event of a crisis- as M alaysia did in September 1998- permitting looser domestic monetary policy. Controls on outflows are ideally taken as a transitional measure to buy time to achieve goals, as an aid to reform rather than as a substitute (Krugman, 1998). Second, controls can prevent destabilizing outflows by discouraging or changing the composition of capital inflows, as Chile did for most of the 1990s.

The second method - to discourage or change the composition of capital inflows with controls- requires some explanation. A prime fear of those who seek to limit capital flows is that sudden outflows may endanger economic stability because investors are subject to panics, fads, and bubbles (Kindl eberger, 1978; Krugman, 1998; Wade and Veneroso, 1998). Investors may panic because they, as individuals, have limited information about the true value of the assets they are buying or selling. They can, however, infer information from the actions of others. For example, one might assume that a crowded restaurant serves good food, even if one has never eaten there. In financial markets, participants learn about other participants' information by watching price movements. An increase in the price of an asset might be interpreted as new information that the asset had been underpriced, for example. Such a process might lead to "herding" behavior, in which asset price changes tend to cause further changes in the same direction, creating a boom-bust cycle and instability in financial markets, potentially justifying capital controls. By discouraging inflows of foreign capital, governments can limit the pool of volatile capital that may leave on short notice.

Instead of limiting the total quantity of capital inflows, some would argue that changing the composition of that inflow is just as important. For example, it often is claimed that direct investment is likely to be more stable than portfolio investment because stocks or bonds can be sold more easily than real assets (like production facilities) can be liquidated (Dixit and Pindyck, 1994; Frankel and Rose, 1996; Dornbusch, 1998). In contrast, Garber (1998) argues that tracking portfolio and direct investment data may be misleading; derivatives (options, futures, swaps, etc.) can disguise the source of a crisis, making it look like the source is excessive shortterm debt. Goldstein (1995) says there is little evidence that direct investment is less "reversible" than portfolio investment. For example, foreign firms with domestic production facilities abroad can use those facilities as collateral for bank loans that then can be converted to assets in another currency, effectively moving the capital back out of the country.

\section{TYPES OF CAPITAL CONTROLS}

To meet the many possible objectives described for them, there are many types of capital controls, distinguished by the type of asset transaction they affect and whether they tax the transaction, limit it, or prohibit it outright. This section distinguishes the many types of capital controls by this taxonomy.

Capital controls are not, strictly speaking, the same as exchange controls, the restriction of trade in currencies, although the two are closely related (Bakker, 1996). Although currency and bank deposits are one type of asset-money- exchange controls may be used to control the current account rather than the capital account. For example, by requiring importers to buy foreign exchange from the government for a stated purpose, exchange controls may be used to prohibit the legal importation of "luxury" goods, thereby rationing "scarce" foreign exchange for more politically desirable purposes. So, while exchange controls are inherently a type of limited capital control, they are neither necessary to restrict capital
18 The capital adequacy standards of the Basle accords penalize long-term international interbank lending relative to shortterm lending, exacerbating the problem (Corsetti, Pesenti, and Roubini, 1998b). Although banks are important and heavily regulated almost everywhere, banks play an especially important role in developing countries because information problems tend to be more important in the developing world than they are in the developed world. 


\section{MALAYSIA'S CAPITAL CONTROLS: 1998-99}

The devaluation of the Thai baht in July 1997 sparked significant capital outflows from Southeast Asia, leading to a fall in local equity prices and plunging exchange rates. To counter these outflows of capital, the IMF urged many of the nations of the region to raise interest rates, making their securities more attractive to international investors. Unfortunately, the higher interest rates also slowed the domestic economies. ${ }^{1}$

In response to this dilemma, Malaysia imposed capital controls on September 1, 1998. The controls banned transfers between domestic and foreign accounts and between foreign accounts, eliminated credit facilities to offshore parties, prevented repatriation of investment until September 1, 1999, and fixed the exchange rate at M 3.8 per dollar. Foreign exchange transactions were permitted only at authorized institutions and required documentation to show they were for current account purposes. The government enacted a fairly intrusive set of financial regulations designed to prevent evasion. In February 1999, a system of taxes on outflows replaced the prohibition on repatriation of capital. While the details are complex, the net effect was to discourage short-term capital flows but to freely permit longer-term transactions (Blustein, 1998). By imposing the capital controls, Malaysia hoped to gain some monetary independence, to be able to lower interest rates without provoking a plunge in the value of the currency as investors fled Malaysian assets.
The Malaysian government and business community claimed to be pleased with the effect of the controls in increasing demand and returning stability to the economy. Even economists who oppose capital controls believe that they may have been of some use in buying time to implement fundamental reforms (Barro, 1998).

Others fear, however, that the capital controls have replaced reform, rather than buying time for reform. As of May 1999, the Malaysian government does not appear to be using the breathing space purchased by the capital controls to make fundamental adjustments to its fragile and highly leveraged financial sector. Rather, Prime M inister Mahathir has sacked policymakers who advocate reform while aggressively lowering interest rates, loosening nonperforming loan classification regulation and setting minimum lending targets for banks. This strategy may prove short-sighted, as much of the capital outflow was caused by the recognition that asset prices were overvalued and the banking sector was weak ( $G$ lobal Investor, 1998b). Although monetary stimulus may be helpful in the short run, it may exacerbate the underlying problems. In addition, the government must be concerned about the long-term impact that the controls will have on investors' willingness to invest in the country.

\footnotetext{
${ }^{1}$ For an overview of the causes and policy options in the Asian financial crisis, see Corsetti, Pesenti, and Roubini (1998a and 1998b).
}

movement nor are they necessarily intended to control capital account transactions.

\section{Controls on Inflows vs. O utflows}

Capital controls on some long-term (more than a year) inflows- direct invest- ment and equity - often are imposed for different reasons than those on short-term inflows- bank deposits and money market instruments. While the recent trend has been to limit short-term capital flows because of their allegedly greater volatility and potential to destabilize the economy, 
bans on long-term capital flows often reflect political sensitivity to foreign ownership of domestic assets. For example, Article 27 of the M exican constitution limits foreign investment in Mexican real estate and natural resources.

Controls on capital inflows and outflows provide some slack for monetary policy discretion under fixed exchange rates, but in opposite directions. Controls on capital inflows, which allow for higher interest rates, have been used to try to prevent an expansion of the money supply and the accompanying inflation, as were those of Germany in 1972-74 (Marston, 1995) or Chile during the 1990s. ${ }^{19}$ In contrast, controls on capital outflows permit lower interest rates and higher money growth than otherwise would be possible ( $M$ arston, 1995). They most often have been used to postpone a choice between devaluation or tighter monetary policy, as they have been in Malaysia, for example (see the shaded insert).

\section{Price vs. Q uantity Controls}

Capital controls also may be distinguished by whether they limit asset transactions through price mechanisms (taxes) or by quantity controls (quotas or outright prohibitions). Price controls may take the form of special taxes on returns to international investment (like the U.S. interest equalization tax of the 1960s- see the shaded insert), taxes on certain types of transactions, or a mandatory reserve requirement that functions as a tax.

One type of price mechanism to discourage short-term capital flows is the "Tobin" tax. Proposed by Nobel laureate James Tobin in 1972, the Tobin tax would charge participants a small percentage of all foreign exchange transactions ( $\mathrm{ul} \mathrm{Haq,}$ Kaul and Grunberg, 1996; Kasa, 1999). Advocates of such a tax hope that it would diminish foreign exchange market volatility by curtailing the incentive to switch positions over short horizons in the foreign exchange market. There are many problems with a Tobin tax, however. The tax might reduce liquidity in foreign exchange markets or be evaded easily through derivative instruments. It is uncertain who would collect the tax or for what purposes the revenue would be used. And, most dauntingly, a Tobin tax would have to be enacted by widespread international agreement to be successful.

A mandatory reserve requirement is a price-based capital control that commonly has been implemented to reduce capital inflows. Such a requirement typically obligates foreign parties who wish to deposit money in a domestic bank account-or use another form of inflow - to deposit some percentage of the inflow with the central bank for a minimum period. For example, from 1991 to 1998, Chile required foreign investors to leave a fraction of short-term bank deposits with the central bank, earning no interest. ${ }^{20}$ As the deposits earn no interest and allow the central bank to buy foreign money market instruments, the reserve requirement effectively functions as a tax on short-term capital inflows (Edwards, 1998b). See the shaded insert on the Chilean encaje of the 1990s.

Quantity restrictions on capital flows may include rules mandating ceilings or requiring special authorization for new or existing borrowing from foreign residents. There may be administrative controls on cross-border capital movements in which a government agency must approve transactions for certain types of assets. Certain types of investment might be restricted altogether as in Korea, where the government has, until recently, restricted long-term foreign investment (Eichengreen, et al. 1999). Forbidding or requiring special permission for repatriation of profits by foreign enterprises operating domestical ly may restrict capital outflows. Capital controls may be more subtle: Domestic regulations on the portfolio choice of institutional investors also may be used as a type of capital control, as they have been in Italy and in South Korea in the past (Bakker, 1996; Park and Song, 1996).

\section{EVALUATING CAPITAL CONTROLS}

The conventional wisdom of the economics profession has been-whatever the problems with destabilizing capital flows or
${ }^{19}$ Recall that capital inflows entail foreign purchases of domestic assets or foreign loans to domestic residents while outflows entail domestic purchases of foreign assets or loans to foreign residents by domestic residents. Under a fixed exchange rate, persistent capital inflows will require an expansion of the money supply or a revaluation while substantial capital outflows will require a contraction.

20The Chilean reserve requirement applied not only to bank deposits but to many types of capital inflows. 


\section{THE U.S. INTEREST EQUALIZATION TAX: 1963-74}

During the late 1950 s and early 1960s, the United States had both a fixed-exchange rate regime for the dolIar (the Bretton-Woods system) and chronic pressures toward bal ance-ofpayments deficits. These strains resulted partly from the fact that interest rates in the rest of the world-especially those in Europe- tended to be higher than those in the United States, making foreign assets look attractive to U.S. residents. ${ }^{1}$ Faced with the unpalatable alternatives of devaluing the dollar or conducting contractionary policies, on July 19, 1963, President Kennedy proposed the Interest Equalization Tax (IET) to raise the prices that Americans would have to pay for foreign assets (Economist, 1964a). ${ }^{2}$

The IET imposed a variable surcharge, ranging from 1.05 percent on one-year bills to 15 percent on equity and bonds of greater than 28.5 years maturity, on U.S. purchases of stocks and bonds from Western Europe, Japan, Australia, South Africa, and N ew Zealand (Congressional Quarterly Service, 1969). Canada and the developing world were exempted from the tax out of consideration for their special dependence on U.S. capital markets. By raising the prices of foreign assets, it was hoped that demand for those assets - and the consequent balance-of-payments deficit-would be reduced or eliminated.

The IET reduced direct outflows to the targeted countries but didn't change total outflows much because investors were able to evade the tax through third countries, like Canada (Pearce, 1995; Kreinen, 1971; Stern, 1973). In addition, because the tax did not cover loans, investment was diverted initially from bond and stock purchases to bank loans. Loans from American banks to firms in Europe and Japan jumped from $\$ 150$ million during the first half of 1963 to $\$ 400$ million during the second half (Economist, 1964b).

To check bank loans to foreign countries, the U.S. Congress enacted the Voluntary Foreign Credit Restraint Program (VFCRP) in February 1965, broadening it in 1966 to limit U.S. short-term capital outflows to other developed countries. In addition, U.S. corporations were asked to voluntarily limit their direct foreign investment. The program was made mandatory in 1968 (Laffer and Miles, 1982; Kreinin, 1971). U.S. capital controls were relaxed in 1969 and phased out in 1974, after the United States left the Bretton-Woods system of fixed-exchange rates (Congressional Quarterly Service, 1973a, 1973b, 1977).

One unintended consequence of the IET was the growth of foreign financial markets-at the expense of U.S. markets - as they inherited the job of intermediating international capital flows. For example, the volume of international borrowing in London rose from $\$ 350$ million in 1962 to more than $\$ 1$ billion in 1963 while the volume of foreign flotations in N ew York fell from $\$ 2$ billion in the first half of 1963 to just over $\$ 600$ million in the next nine months (Economist, 1964b).

\footnotetext{
1 At this time, the United States had a current account surplus that failed to fully offset private demand for foreign assets- the capital account deficit- resulting in the need for temporary measures to close the gap.

2 In August 1964, the U.S. Congress enacted this tax, making it retroactive to the date it was proposed.
} 


\section{REVIEW}

\section{CHILE'S ENCAJ E: 1991-98}

During the late 1980s and early 1990s, international capital began to return to Chile as a result of slow growth and low interest rates in the developed world and sound macroeconomic policies, including reduced debt, in Chile (Edwards, 1998a). The Chilean authorities feared that these capital inflows would complicate monetary policy decisions - perhaps causing real appreciation of the exchange rate- and they also were wary of the danger of building up short-term debt.

Chile had long restricted capital flows and these limits were updated in the early 1990s to deal with the surge in capital inflows. Direct investment was made subject to a 10-year stay requirement in 1982; this period was reduced to three years in 1991 and to oneyear in 1993. Portfolio flows were made subject to the encaje- a one-year, mandatory, non-interest paying deposit with the central bank - created in 1991 to regulate capital inflows. ${ }^{1}$ The encaje was initially 20 percent but was increased to 30 percent in 1992. The penalty for early withdrawal was 3 percent. ${ }^{2}$

The effect of the encaje was to tax foreign capital inflows, with short-term flows being taxed much more heavily than long-term flows. For example, consider the choice of an American buying a one-year discount bond with a face value of 10,000 pesos for a price of 9,091 pesos, or a 10-year discount bond with the same face value and a price of 3,855 pesos. Either bond, if held to maturity, would yield a 10 percent per annum return. ${ }^{3}$ In the presence of a 30 percent one-year reserve requirement, however, the one-year bond's annual yield would be 7.7 percent and the 10-year bond's annual yield would be 9.7 percent. Hence, theencaje acted as a graduated tax on capital inflows.

Researchers disagree about the effectiveness of Chile's capital controls. Valdes and Soto (1996) concluded that they changed the composition but not the magnitude of the inflows. In other words, investors substituted from heavily taxed short-term flows to more lightly taxed long-term inflows. They also found that the controls were ineffective in preventing a real appreciation of the exchange rate. Larraín B., Labán M., and Chumacero (1997) studied the same issue with different methods and found that, although there was considerable substitution in the short run, the controls did change the magnitude of the inflows in the long run.

There is even more disagreement about whether the capital controls were important in keeping Chile insulated from the Asian crisis. Many observers have cited Chile's capital controls in advocating more widespread restrictions on capital controls for other developing countries (Bhagwati, 1998). Edwards (1998a), on the other hand, points out that Chile also had substantial capital controls during the late 1970 s and early 1980s, before its major banking crisis that cost Chileans more than 20 percent of GDP during 1982-83. The major difference between then and now is that Chile now has a modern and efficient system of banking regulation. Others credit the participation of foreign banks in strengthening the Chilean banking system by providing experience and sophistication in assessing risks and making loans. At the time of the crisis, Chile had a high percentage of domestic loans from foreign-owned banks-20 percent, about the same as the U nited States and far higher than South Korea, Thailand, and Indonesia (5 percent) (Economist, 1997). In addition, Edwards (1998a) claims that the encaje harmed the domestic financial services industry and the small firms that could not borrow long term on international markets to avoid the tax. If Chiles capital controls helped, it was to buy time for structural reforms and effective financial regulation.

1 The word encaje means "strongbox" in Spanish.

2 The encaje was reduced to 10 percent and the early withdrawal penalty from 3 percent to 1 percent in J une 1998. The encaje was eliminated entirely on September 16, 1998 (Torres, 1998).

3 The yield to maturity on a bond equates the initial outlay with the present discounted value of its payoffs. The yields on the bonds are determined by solving the following equations fori:

$9091=10,000 /(1+i), 3855=10,000 /(1+i)^{10}$,

$1.3 * 9091=.3 * 9091 /(1+i)+10,000 /(1+i)$ and

$1.3 * 3855=.3 * 3855 /(1+i)+10,000 /(1+i)^{10}$. 
fixed exchange rates- that capital controls are ineffective and impose substantial costs on economies that outweigh any benefits. That generalization ignores distinctions among types of capital controls and varied criteria for success, however. Capital controls have many potential purposes and thus many potential standards by which to judge their efficacy. Difficulties in separating the effects of capital controls from the balance of payments or capital flow problems they were intended to alleviate complicates the empirical study of the effects of capital controls (Johnston and Tamirisa, 1998). Also, generalizing about the effectiveness of capital controls from one country-or even one period- to another is risky because the effectiveness of capital controls depends on the rigor with which they are enforced (Obstfeld and Taylor, 1998). Governments that control substantial aspects of their citizens' lives (e.g., Cuba) find it easier to enforce controls on trade in assets (M inton, 1999).

\section{Are Capital Controls Effective?}

Keeping in mind these difficulties, there are several possible ways to gauge the effectiveness of capital controls. Perhaps

${ }^{21}$ An (American) put option confers on the holder the right, but not the obligation, to sell a specified quantity of pesos at a specified price, called the strike price or exercise price, on or before a given date.

22 Fieleke (1994) finds that capital controls were of very limited effectiveness in creating interest differentials during the European Monetary System crises of 1992-93.

${ }^{23} \mathrm{As}$ will be discussed in the next subsection, capital controls often are evaded by changing from prohibited to permitted assets or by falsifying invoices for traded goods.

24 The continuously compounded annual return is computed from $52 * \ln (.9 / 1)$. the most direct way is to measure whether the imposition of capital controls changes the magnitude or composition of capital flows, using some assumption about what flows would have been without the capital controls. M easuring the composition of capital flows always has been difficult, however, and it has become more so since the advent of derivatives that can be used to disguise capital flows. For example, a U.S. firm may build a production facility in Mexico but hedge the risk that the peso will declinereducing the dollar value of the investment- by buying put options on the peso, which will increase in value if the peso falls. ${ }^{21}$ The direct investment will be measurable as an inflow, but the corresponding outflow - the put contract to potentially sell pesos_- may not be (Garber, 1998).

If capital controls are designed to permit monetary autonomy, one can examine the extent to which onshore interest rates-subject to capital controls- differ from those found in offshore markets or domestic currency returns on foreign assets. Such tests assume that returns on comparable investments in the same currency should be equal in the absence of effective capital controls. To the extent that they differ, the capital controls are effective (Harberger, 1980; Edwards, 1998b). This research has shown that capital controls have been able to create modest "wedges" of one to several percentage points between returns on similar domestic and international assets ( $M$ arston, 1995).22 A related test to determine monetary autonomy is to measure the effectiveness of sterilization in preventing an appreciation of the real exchange rate.

Generally, controls on inflows have been found to be more effective than those on outflows because there is less incentive to evade controls on inflows (Reinhart and Smith, 1998; Eichengreen, et al. 1999).23 Evading controls on inflows ordinarily will provide only marginal benefits for foreign investors, as the expected risk-adjusted domestic return usually will be comparable to that on al ternative international investments. On the other hand, in the event of an expected devaluation, there is enormous incentive to avoid such a loss by evading controls on capital outflows. The expected loss on holding domestic assets can be several hundred percent in annualized terms over a short horizon. For example, if one expects the Malaysian ringgit to be devalued 10 percent in one week, the expected continuously compounded annual return associated with holding the currency through such a devaluation is almost - 550 percent. ${ }^{24}$ Therefore, researchers like Obstfeld (1998) and Eichengreen (1999) have found the idea of preventing destabilizing outflows by limiting inflows to be more promising than directly trying to stop outflows.

In sum, the consensus of the research on capital controls has been that they can alter the composition of capital flows or drive a small, permanent wedge between domestic and offshore interest rates but they cannot indefinitely sustain inconsis- 
tent policies, and their effectiveness tends to erode over time as consumers and firms become better at evading the controls (Marston, 1995). Outflow restrictions, in particular, may buy breathing space, but that is all. There are more researchers willing to defend inflow restrictions, however. Eichengreen (1999) argues that, to restrain inflows, controls do not have to be perfect, they just need to make avoidance costly enough to reduce destabilizing flows.

\section{How Are Capital Controls Evaded?}

Over time, consumers and firms realize that they can evade capital controls through the channels used to permit trade in goods. Firms, for example, may evade controls on capital flows by falsifying invoices for traded goods; they apply to buy or sell more foreign exchange than the transaction calls for. For example, a domestic firm wishing to evade limits on capital inflows might claim that it exported $\$ 10$ million worth of goods when it only, in fact, exported $\$ 9$ million. It may use the excess $\$ 1$ million to invest in domestic assets and split the proceeds with the foreign firm providing the capital.

Perhaps the most common method to evade controls on capital flows is through "leads and lags" in which trading firms hasten or delay payments for imports or exports (Einzig, 1968). To evade controls on outflows, for example, importers pay early for imports (leads), in exchange for a discount, and exporters allow delayed payments for their goods (lags), in return for a higher payment. This permits importers and exporters to effectively lend money to the rest of the world, a capital outflow. To evade controls on inflows, importers delay payments while exporters demand accelerated payments. Thus, leads and lags permit trade credit to substitute for short-term capital flows. Governments often attempt to close the leads/lags loophole on shortterm capital flows with administrative controls on import/export financing.

Travel allowances for tourists are another method by which capital controls may be evaded (Bakker, 1996). More recently, financial innovation has spawned financial instruments-derivatives - that may be used to mislead banking and financial regulators to evade prudential regulation and/or capital controls (Garber, 1998). For example, derivatives may contain clauses that change payouts in the event of defaults or the imposition of exchange controls (Garber, 1998). Improvements in information technology make it easier to buy and sell assets and reduce the effectiveness of capital controls (Eichengreen, et al. 1999).

Capital controls al so induce substitution from prohibited to permitted assets (Goldstein, 1995). So, for example, the U.S. interest equalization tax was evaded through trade in assets with Canada while heavy Chilean taxes on short-term inflows may have induced a (desired) substitution to more lightly taxed longer-term inflows (Valdes, 1998). Capital controls have been more successful in changing the composition of asset trade than the volume.

\section{Costs of Capital Controls}

Although they often are evaded successfully, capital controls nonetheless impose substantial costs in inhibiting international trade in assets. Foremost among these costs are limiting the benefits of capital flows as described in Section 2: risk-sharing, diversification, growth, and technology transfer (Global Investor, 1998a). Capital exporting countries see a lower return on their savings while capital importers receive less investment and grow more slowly with capital controls. Krugman (1998) argues that capital controls do the most harm when they are used to defend inconsistent policies that produce an overvalued currency-a currency that would tend to depreciate or be devalued in the absence of the controls. This attempt to free governments from the discipline of the market permits poor or inconsistent policies to be maintained longer than they otherwise would, increasing the costs of these policies. Poorly designed or administered capital controls often adversely affect direct investment and the ordinary financing of 
trade deals (Economist, 1998). Controls can even worsen the problem of destabilizing capital flows. For example, the Korean government has acknowledged that the restriction on offshore borrowing by Korean corporations contributed to its balance of payments and banking crises in 1997 (Global Investor, 1998a). The corruption created by evasion and the administrative costs of controls also is an unintended cost of the controls. Even as the costs accumulate and their original purpose has ended, capital controls, like any regulation, develop their own constituencies and become difficult to phase out. The resumption of free capital flows does not always end the costs of capital controls. Specifically, blocking the departure of capital temporarily subsidizes investment but raises the perception of risk, increasing a risk premium and/or deterring future investment (Economist, 1998; Goldstein, 1995).

Partly because the costs of capital controls are serious and tend to worsen over time, economists have suggested attacking problems at their source rather than with capital controls (Krugman, 1998; Mishkin, 1998). For example, to cope with banks' incentive to take on excessive risk, a government might concentrate on reforming and strengthening the domestic financial structure- especially regulations on foreign borrowing-as it slowly phases out capital controls to derive the benefits of capital flows (Goldstein, 1995). ${ }^{25}$ Or, to fight a real appreciation brought on by a capital inflow, a government might conduct contractionary

${ }^{25}$ An important but unresolved issue is the sequencing of reforms of the current account, the capital account, and the financial sector. Many blame the recent Asian crisis on the fact that the Asian governments moved faster to liberalize international capital flows than they did to regulate their financial system. In contrast, Sweeney (1997) argues for early liberalization of the capital account to provide accurate pricing information for business decisions. fiscal policy. In all circumstances, better macroeconomic policy is needed to avoid financial crises, such as those that affected Asia in 1997. Countries must eschew overvalued currencies, excessive foreign debt, and unsustainable consumption.

\section{CONCLUSION}

Recently, a number of opinion leaders, including some prominent economists, have suggested that developing countries should reconsider capital controls. This article has reviewed the issues associated with capital controls. Controls most often have been used to permit more freedom for monetary policy during balance of payments crises in the context of fixed exchange rates. Restrictions on inflows have been implemented to prevent real appreciation of the exchange rate or to correct other pre-existing distortions, like the incentives for financial institutions to take excessive risk. Although controls on capital flows may change the composition of flows, they impose substantial costs on the economy and cannot be used to indefinitely sustain inconsistent policies. Under most circumstances, it is better to attack the source of the distortion or inconsistent policy at the source rather than treating symptoms through capital controls.

Although the worst of the Asian financial crisis seems to be over, it- like the peso crisis of December 1994- has been a sobering lesson in the volatility of capital flows and the fragility of emerging market financial systems. It al so has raised questions for future research: Are limits on capital inflows the best solution to protecting domestic financial systems from the distortions inherent in banking? What is the proper sequence for economic reforms of the capital account, the current account, and the banking system?

\section{REFERENCES}

Alesina, Alberto, Vittorio Grilli, and Gian Maria Milesi-Ferretti. "The Political Economy of Capital Controls," in Capital Mobility: The Impact on Consumption, Investment, and Growth, Leonardo Leiderman and Assaf Razin, eds., Cambridge University Press, 1994, pp. 289-321.

Bakker, Age F.P. The Liberalization of Capital Movements in Europe, Kluwer Academic Publishers, 1996.

Barro, Robert. "Malaysia Could Do Worse than this Economic Plan," Business Week, November 2, 1998, p. 26.

Bernanke, Ben S. "Nonmonetary Effects of the Financial Crisis in Propagation of the Great Depression," American Economic Review (June 1983), pp. 257-76.

Bhagwati, Jagdish. "Why Free Capital Mobility may be Hazardous to Your Health: Lessons from the Latest Financial Crisis," NBER Conference on Capital Controls, November 7, 1998.

Blustein, Paul. "Is Malaysia's Reform Working? Capital Controls Appear to Aid Economy, but Doubts Remain," Washington Post, November 21, 1998, p. G01. 


\section{REVIEW}

NOVEMBER/ DECEMBER 1999

Congressional Quarterly Service. "Interest Equalization Tax Background," Congress and the Nation, 1965-1968, Vol. II, 1969, p. 144.

. "Foreign Investment Controls," Congress and the Nation, 1969-1972, Vol. III, 1973a, p. 123.

. "1971 Smithsonian Agreement Broke Down in 14 Months," Congress and the Nation, 1969-1972, Vol. III, 1973b, p. 133.

"Interest Equalization Tax," Congress and the Nation, 1973-1976, Vol. IV, 1977, p. 85.

Corbo, Vittorio, and Leonardo Hernandez. "Macroeconomic Adjustment to Capital Inflows: Lessons from Recent Latin American and Asian Experiences," World Bank Research Observer (February 1996), pp. 61-85.

Corsetti, Giancarlo, Paolo Pesenti, and Nouriel Roubini. "What Caused the Asian Currency and Financial Crisis? Part I: A Macroeconomic Overview," NBER Working Paper 6833, December 1998a.

. "What Caused the Asian Currency and Financial Crisis? Part Il: The Policy Debate," NBER Working Paper 6834, December 1998b.

Department of Commerce. The Balance of Payments of the United States: Concepts, Sources and Estimation Procedures, U.S. Government Printing Office, 1990.

Diamond, Douglas W., and Philip H. Dybvig. "Bank Runs, Deposit Insurance, and Liquidity," Joumal of Political Economy (June 1983), pp. 401-19.

Dixit, Avinash K., and Robert S. Pindyck. Investment Under Uncertainty, Princeton University Press, 1994.

Dooley, Michael P. "A Survey of Literature on Controls of International Capital Transactions," IMF Staff Papers (December 1996), pp. 639-87.

Dombusch, Rudiger. "Capital Controls: An Idea Whose Time is Past," in Should the IMF Pursue Capital-Account Convertibility?, Princeton Essays in International Finance No. 207, May 1998, pp. 20-27.

Economist. "One Year Old and Not Yet Born?" July 18, 1964a, p. 283. pp. $565-67$

"Where Will all the Borrowers Go?" August 4, 1964b,

. _. _ _ _ . "How Far is Down?" November 15, 1997, pp. 19-21.

"The Perils of Global Capital," April 11, 1998, pp. 52-54.

Edwards, Sebastian. "Capital Controls Are Not the Reason for Chile's Success," Wall Street Joumal, April 3, 1998a, p. A19.

. "Capital Flows, Real Exchange Rates and Capital Controls: Some Latin American Experiences," NBER Working Paper 6800, November 1998b.

Eichengreen, Barry. Toward a New Intemational Financial Architecture: A Practical Post-Asia Agenda, Institute for International Economics, 1999.

Michael Mussa, Giovanni Dell'Ariccia, Enrica Detragiache, Gian Maria Milesi-Ferretti, and Andrew Tweedie. "Liberalizing Capital Movements: Some Analytical Issues," IMF Economic Issue No. 17, February 1999.
Einzig, Paul. Leads and Lags, MacMillan and Company, 1968.

Fieleke, Norman S. " International Capital Transactions: Should They Be Restriced?" New England Economic Review (March/ April 1994), pp. 27-39.

Frankel, Jeffrey A., and Andrew K. Rose. "Currency Crashes in Emerging Markets: An Empirical Treatment," Joumal of International Economics (November 1996), pp. 351.66.

Friedman, Mitton, and Anna Schwartz. A Monetary History of the United States, 1867-1960, Princeton University Press, 1963.

Garber, Peter. "Derivatives in International Capital Flow," NBER Working Paper 6623, June 1998.

Global Investor. "Managing Currency Risk in Tumultuous Times," Emerging Market Currencies: A Guide for Investors Supplement (October 1998a), pp. 2-4.

. "Malaysia's Exchange Controls: Delaying the Inevitable," Emerging Market Currencies: A Guide for Investors Supplement (October 1998b), pp. 12-14.

Goldstein, Morris. "Coping with Too Much of a Good Thing: Policy Responses for Large Capital Inflows to Developing Countries," Institute for Intermational Economics, 1995.

Grilli, Vittorio, and Gian Maria Milesi-Ferretti. "Economic Effects and Structural Determinants of Capital Controls," IMF Staff Papers (September 1995), pp. 517-51.

Harberger, Arnold C. "Vignettes on the World Capital Market," American Economic Review (May 1980), pp. 331-37.

. . . . "Economic Adjustment and the Real Exchange Rate," in Economic Adjustment and Exchange Rates in Developing Countries, Sebastian Edwards and Liaquat Ahamed, eds., University of Chicago Press, 1986, pp. 371-414.

Johnston, Barry R., and Natalia T. Tamirisa. "Why Do Countries Use Capital Controls?" IMF Working Paper 98-181, December 1998.

Kaminsky, Graciela L., and Carmen M. Reinhart, "The Twin Crises: The Causes of Banking and Balance of Payments Problems," American Economic Review (J une 1999), pp. 473-99.

Kasa, Kenneth. "Time for a Tobin Tax?" FRBSF Economic Letter 99-12, April 9, 1999.

Kindleberger, Charles P. Manias, Panics, and Crashes: A History of Financial Crises, Macmillan, 1978.

Kreinin, Mordechai. International Economics: A Policy Approach, Harcourt, Brace, Jovanovich, 1971.

Krugman, Paul. "An Open Letter to Prime Minister Mahathir," September 1, 1998.

Laffer, Arthur, and Marc A. Miles. Intemational Economics in an Integrated World, Scott, Foresman and Company, 1982.

Larraín B., Felipe, Rául Labán M., and Rómulo A. Chumacero. "What Determines Capital Inflows?: An Empirical Analysis for Chile," Faculty Research Working Paper Series, Kennedy School of Government, Harvard University, 97-09, April 1997. 
Marston, Richard C. Intemational Financial Integration: A Study of Interest Differentials Between the Major Industrial Countries, Cambridge University Press, 1995.

McKinnon, Ronald I., and Wallace E. Oates. "The Implications of International Economic Integration for Monetary, Fiscal and Exchange Rate Policies," The International Finance Section, Princeton University, 1966.

Minton, Zinny, "Global Finance Survey: A Wealth of Blueprints," Economist, January 30, 1999, pp. 55-58.

Mishkin, Frederic S. "International Capital Movements, Financial Volatility and Financial Instability," NBER Working Paper 6390, January 1998.

Mitchell, B.R. Intemational Historical Statistics: Africa, Asia \& Oceania 1750-1993, Macmillan Reference, 1998.

New York Times. "How U.S. Wooed Asia to Let Cash Flow In," February 16, 1999, p. Al.

Obstfeld, Maurice. "The Global Capital Market: Benefactor or Menace?" Working Paper, 1998.

_..... and Alan M. Taylor. "The Great Depression as a Watershed: International Capital Mobility over the Long Run," in The Defining Moment: The Great Depression and the American Economy in the Twentieth Century, Michael D. Bordo, Claudia D. Goldin, and Eugene N. White, eds., University of Chicago Press, 1998, pp. 353-402.

Park, Yung Chul, and Chi-Young Song. "Managing Foreign Capital Flows: The Experiences of Korea, Thailand, Malaysia and Indonesia," Jerome Levy Economics Institute Working Paper 163, May 1996.
Pearce, David W., ed. MIT Dictionary of Modem Economics, MIT Press, 1995.

Reinhart, Carmen M., and R. Todd Smith. "Too Much of a Good Thing: The Macroeconomic Effects of Taxing Capital Inflows," in Managing Capital Flows and Exchange Rates: Perspectives from the Pacific Basin, Reuven Glick, ed., Cambridge University Press, 1998, pp. $436-64$.

Stem, Robert. The Balance of Payments: Theory and Economic Policy, Aldine Publishing Company, 1973.

Sweeney, Richard J. "The Information Costs of Capital Controls," in Capital Controls in Emerging Economies, Christine P. Ries and Richard J. Sweeney, eds, Westview Press, 1997, pp. 45-61.

Torres, Craig. "Chilean Bid to Boost Confidence Lauded," Wall Street Journal, June 29, 1998, p. A14.

ul Haq, Mahbub, Inge Kaul, and Isabelle Grunberg, eds. The Tobin Tax: Coping with Financial Volatility, Oxford University Press, 1996.

Valdes, Salvador. "Capital Controls in Chile Were a Failure," Wall Street Journal, December 11, 1998, p. A15.

_. . and Marcelo Soto. "New Selective Capital Controls in Chile: Are they Effective?" Catholic University of Chile Working Paper, 1996.

Wade, Robert, and Frank Veneroso. "The Gathering Support for Capital Controls," Challenge (Novemberl December 1998), pp. 14-26. 